\title{
Zinc Fertilization Methods on Zinc Absorption and Translocation in Wheat
}

\author{
Aiqing Zhao \\ College of Resources and Environment, Northwest A\&F University \\ South Campus of Northwest A\&F University, No 3, Taicheng Road \\ Yangling 712100, Shaanxi, China
}

Tel: 86-29-8708-2785 E-mail: aiqing_zhao@,hotmail.com

Xinchun Lu

College of Resources and Environment, Northwest A\&F University

South Campus of Northwest A\&F University, No 3, Taicheng Road

Yangling 712100, Shaanxi, China

Tel: 86-29-8708-2785 E-mail: luxinchun@163.com

\section{Zihui Chen}

College of Resources and Environment, Northwest A\&F University

South Campus of Northwest A\&F University, No 3, Taicheng Road

Yangling 712100, Shaanxi, China

Tel: 86-29-8708-2785 E-mail: zihui.yan@yahoo.com.cn

Xiaohong Tian (Corresponding author)

College of Resources and Environment, Northwest A\&F University

South Campus of Northwest A\&F University, No 3, Taicheng Road

Yangling 712100, Shaanxi, China

Tel: 86-29-8708-2069Ｅ-mail: txhong@hotmail.com, txhong@,nwsuaf.edu.cn

Xiwen Yang

College of Resources and Environment, Northwest A\&F University

South Campus of Northwest A\&F University, No 3, Taicheng Road

Yangling 712100, Shaanxi, China

Tel: 86-29-8708-2785_E-mail: yangxwemail@163.com

We are deeply indebted to National Natural Sciences Foundation of China (31071863, 40971179) and the New-Century Excellent Talent Program of the Education Ministry of China (NCET-06-0866) as well as "Innovative Research Team Program of Northwest A\&F University" for their support to this study.

\footnotetext{
Abstract

To increase grain $\mathrm{Zn}$ concentration of wheat grown on calcareous soil, field and hydroponic culture experiments were conducted to investigate the effects of various $\mathrm{Zn}$ fertilization methods on $\mathrm{Zn}$ absorption and translocation in wheat. A completely randomized block design was used in the field experiment comprising five $\mathrm{Zn}$ treatments $\left(0,7.5,15,30\right.$, and $45 \mathrm{~kg} \mathrm{Zn} / \mathrm{ha}$ as $\left.\mathrm{ZnSO}_{4} \cdot 7 \mathrm{H}_{2} \mathrm{O}\right)$ and wheat cultivar (Zhengmai 9023). The hydroponic
} 
experiment used a completely randomized block design with two factors ( $\mathrm{n}$ supplementation to root and foliar spray of $\mathrm{Zn}$ ). Results showed that in the field experiment, $\mathrm{Zn}$ fertilization significantly increased the amount of soil diethylene triamine penlaacetic acid-Zn (DTPA-Zn), whereas there was no significant effect on $\mathrm{Zn}$ concentration in grain. Furthermore, the utilization rate of $\mathrm{Zn}$ fertilizer was only $0.98 \%, 0.64 \%, 0.29 \%$, and $0.14 \%$ with treatments of $7.5,15,30$, and $45 \mathrm{mg} \mathrm{Zn} \mathrm{ha}^{-1}$, respectively. In contrast, the hydroponic experiment showed that both foliar spray and $\mathrm{Zn}$ supplied to roots significantly increased $\mathrm{Zn}$ concentration in grain, with the greatest concentration found in shoots. Results suggested that lower absorption and translocation were the inhibitory factors to increase grain $\mathrm{Zn}$ concentration in calcareous soil. Consequently, $\mathrm{Zn}$ fertilization to potentially $\mathrm{Zn}$-deficient calcareous soils is not effective method to increase grain $\mathrm{Zn}$ concentration.

Keywords: $\mathrm{Zn}$ foliar spray, $\mathrm{Zn}$ absorption, $\mathrm{Zn}$ translocation, Calcareous soil, Wheat, Hydroponic

\section{Introduction}

Zinc is an important essential trace element for both plants and humans (Kaya et al., 1999; Asad and Rafique, 2000; Hao et al., 2007). However, Zn deficiency appears to be the most widespread and frequent micronutrient deficiency in crops worldwide, resulting in severe losses in yield and nutritional quality. Zn deficiency in humans is a critical nutritional and health problem in the world (WHO, 2002; Alloway, 2004; Gunes et al., 2007). It affects, on average, one-third of the world's population, ranging from 4 to $73 \%$ in different countries (Hotz and Brown, 2004). In China, Zn deficiency was also prevalent, with $60 \%$ of children suffering from $\mathrm{Zn}$ deficiency (Yang, 2007). In developing countries, a large proportion of dietary intake of $\mathrm{Zn}$ is derived from cereal grains. The concentration of $\mathrm{Zn}$ in cereal grains is generally low and the bioavailability is also reduced due to the existence of anti-nutrition factors such as phytic acid. Increasing $\mathrm{Zn}$ concentration of cereal grains has been identified as a way of addressing human Zn deficiency (Garnett and Graham, 2005; Muminjanov et al., 2007; Pahlavan-Rad and Pessarakli, 2009).

A number of attempts have been made to increase $\mathrm{Zn}$ concentration in grain crops. An important strategy for increasing micronutrient concentration in grain is breeding or cultivating more resistant genotypes (cultivars). However, the environment can have significant effects on grain $\mathrm{Zn}$ concentration and there is significant interaction between genotype and the environment (Cakmak et al., 2004). In addition, genotypic variation for grain $\mathrm{Zn}$ concentration among wheat cultivars is relatively narrow and limited. Use of $\mathrm{Zn}$ in soil amendments and as foliar sprays have gained acceptance in recent days. Studies have shown that soil amendment with $\mathrm{Zn}$ fertilizer increased $\mathrm{Zn}$ concentration in wheat grain in soil with extreme $\mathrm{Zn}$ deficiency (Yilmaz et al., 1997; Cakmak, 2002). Yilmaz et al. (1997) found that foliar $\mathrm{Zn}$ supplementation could increase $\mathrm{Zn}$ concentration in grain. A two-year field experiment showed that foliar application of $\mathrm{Zn}$ significantly increased $\mathrm{Zn}$ concentration in wheat grain (Pahlavan-Rad and Pessarakli, 2009).

However, increased $\mathrm{Zn}$ concentration in grain due to fertilization is mainly associated with extreme $\mathrm{Zn}$ deficient soils, such as in Turkey (Cakmak, 1996; 1999). In China, wheat is mainly grown on calcareous soils in which $\mathrm{Zn}$ is potentially deficient, with DTPA- $\mathrm{Zn}$ on average being $0.51 \mathrm{mg} / \mathrm{kg}$. In calcareous soils there are many factors to affect $\mathrm{Zn}$ availability, such as high $\mathrm{pH}$, high $\mathrm{CaCO}_{3}$ and low organic matter (Graham and Rengel, 1993; Alloway, 2008). The lower bioavailability of $\mathrm{Zn}$ in soil directly affects grain $\mathrm{Zn}$ concentration and human health. However, $\mathrm{Zn}$ fertilization on calcareous soil showed no significant effects on grain $\mathrm{Zn}$ concentration (Hao et al., 2003). Little is known about mechanisms of $\mathrm{Zn}$ absorption in calcareous soils and $\mathrm{Zn}$ translocation within wheat plants. In this experiment, we tested for factors inhibiting $\mathrm{Zn}$ absorption in wheat cultivated on calcareous soil.

\section{Materials and Methods}

\subsection{Field Experiment}

A field experiment was conducted at No. 1 Experiment Farm, Northwest A\&F University (China) on a potentially Zn-deficient calcareous soil. The altitude of the area is $525 \mathrm{~m}$ and the climate is semi-humid prone to drought with an average annual temperature of $13^{\circ} \mathrm{C}$ and average annual rainfall of $600 \mathrm{~mm}$. Some characteristics of soils at the experimental site at $0-20 \mathrm{~cm}$ depth are in Table 1.

The experimental design was complete randomized block design with three replications comprising five $\mathrm{Zn}$ treatments $\left(0,7.5,15,30\right.$, and $45 \mathrm{~kg} \mathrm{Zn} / \mathrm{ha}$ as $\left.\mathrm{ZnSO}_{4} \cdot 7 \mathrm{H}_{2} \mathrm{O}\right)$ and wheat cultivar Zhengmai 9023 . The following treatment codes will be used throughout the paper: $\mathrm{Zn}_{0}, \mathrm{Zn}_{7.5}, \mathrm{Zn}_{15}, \mathrm{Zn}_{30}$, and $\mathrm{Zn}_{45}$. Plantings were done on 18 October 2008 at a seeding rate of 500 grains $\mathrm{m}^{-2}$. The area of each plot was $3 \mathrm{~m} \times 4 \mathrm{~m}=12 \mathrm{~m}^{2}$. There were 15 plots, with $30 \mathrm{~cm}$ between plots and $1 \mathrm{~m}$ between blocks. During planting $120 \mathrm{~kg} \mathrm{P}_{2} \mathrm{O}_{5} \mathrm{ha}^{-1}$ supplied as superphosphate and $100 \mathrm{~kg} \mathrm{~N} \mathrm{ha}^{-1}$ in the form of urea were applied as the basic fertilizers with an experimental drill. Wheat was harvested at full maturity. At early and late growth stages, soil samples were collected once a week, and at the 
wintering and jointing stages soil samples were collected once a month.

\subsection{Hydroponic culture experiment}

A nutrient solution culture experiment was conducted in the Hydroponic Culture Lab, College of Resources and Environment, Northwest A\&F University from March to June, 2008. Zhengmai 9023, as the test cultivar, is not sensitive to $\mathrm{Zn}$ deficiency. Wheat seeds were soaked in $55^{\circ} \mathrm{C}$ water for $15 \mathrm{~min}, 3 \% \mathrm{H}_{2} \mathrm{O}_{2}$ for $10 \mathrm{~min}$, and then distilled water for $3 \mathrm{~h}$. The seeds were germinated for 5 days (d) on moist filter paper, and seedlings were transferred to $4^{\circ} \mathrm{C}$ to vernalize for $20 \mathrm{~d}$. Seedlings were then selected for uniformity and transplanted into $1 \mathrm{~L}$ opaque containers, each covered with a polystyrol-plate with five holes. One seedling was fixed in each hole and one hole was used as an inlet for an aeration tube. A modified Hoagland solution was used with the following composition in $\mathrm{mg} / \mathrm{L}$ : $\mathrm{Ca}\left(\mathrm{NO}_{3}\right)_{2} \cdot 4 \mathrm{H}_{2} \mathrm{O} 950, \mathrm{KNO}_{3} 610, \mathrm{MgSO}_{4} \cdot 7 \mathrm{H}_{2} \mathrm{O} 490, \mathrm{NH}_{4} \mathrm{H}_{2} \mathrm{PO}_{4}$ 120, Fe-citrate 0.0025 plus in $\mathrm{mg} / \mathrm{L}: \mathrm{H}_{3} \mathrm{BO}_{3} 2.86, \mathrm{MnCl}_{2} \cdot 4 \mathrm{H}_{2} \mathrm{O} 1.81, \mathrm{CuSO}_{4} \cdot 5 \mathrm{H}_{2} \mathrm{O} 0.08, \mathrm{H}_{2} \mathrm{MoO}_{4} \cdot 4 \mathrm{H}_{2} \mathrm{O} 0.09$. All chemicals were Analytical reagent (AR). The plants were grown in $1 / 2$ strength Hoagland solution for one week, the solution was then replaced with full strength Hoagland solution with $\mathrm{ZnSO}_{4} \cdot 7 \mathrm{H}_{2} \mathrm{O}$. The nutrient solution was aerated continuously. The pots were arranged on a laboratory bench in a completely randomized block design. The containers were kept in a growth chamber with day/night temperatures of $25 / 15^{\circ} \mathrm{C}$ and a 10 hour-photoperiod at $550 \mu \mathrm{mol} \mathrm{m} \mathrm{m}^{-2} \mathrm{~s}^{-1}$. The full strength nutrient solution in the pots was replaced on the fourth day. Plants were harvested two months after transplanting the seedlings to the nutrient solutions.

The experimental design was completely randomized blocks with two factors consisting of two levels of $\mathrm{Zn}$ supplementation in hydroponic medium $(0 \mu \mathrm{mol} / \mathrm{L}$ and $3 \mu \mathrm{mol} / \mathrm{L})$ and $\mathrm{Zn}$ treatment of leaves $(0.15 \%$ $\mathrm{ZnSO}_{4} \cdot 7 \mathrm{H}_{2} \mathrm{O}, 0.48 \mathrm{~mL} / \mathrm{plant}$ ) at the jointing, heading and flowering stages. The control treatment was sprayed with distilled water. The following treatment codes will be used throughout the paper: $\mathrm{Zn}_{0}, \mathrm{Zn}_{3}$ and $\mathrm{S}_{\mathrm{Water}}$, $\mathrm{S}_{\text {Jointing, }}$, $\mathrm{S}_{\text {Heading, }}, \mathrm{S}_{\text {Flowering. }}$. Each treatment was replicated four times.

\subsection{Chemical and statistical analyses}

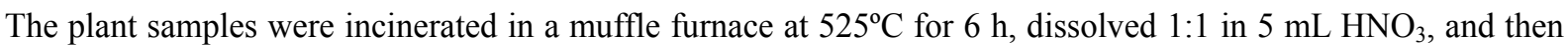
transferred to $50 \mathrm{~mL}$ volumetric flasks and brought to volume with distilled water. The solutions were analyzed with an atomic absorption spectrophotometer (AA320CRT, Shanghai Analytical Instrument Overall Factory, China) to determine $\mathrm{Zn}$ concentration.

The available $\mathrm{Zn}$ in the initial and post harvest soil samples was extracted with DTPA solution and the quantity was estimated with AAS (AA320CRT).

The results were analyzed statistically by analysis of variance and multiple comparisons of means according to standard procedures using Excel 2003 and DPS 3.01 statistical software (Ruifeng Information Technology Ltd. Co, Hangzhou, China). The level of significance $(\alpha)$ was 0.05 ( $P \leq 0.05)$.

$\mathrm{Zn}$ accumulation $=\mathrm{Zn}$ concentration $\times$ biomass yield

$\mathrm{Zn}$ utilization rate $=($ aboveground part $\mathrm{Zn}$ accumulation in - the $\mathrm{Zn}$ treatment $) / \mathrm{Zn}$ fertilizer level

Root\%=root $\mathrm{Zn}$ accumulation/plant $\mathrm{Zn}$ accumulation

Shoot $\%=$ shoot $\mathrm{Zn}$ accumulation/plant $\mathrm{Zn}$ accumulation

Grain\%=grain $\mathrm{Zn}$ accumulation/plant $\mathrm{Zn}$ accumulation

\section{Results}

\subsection{Field Experiment}

\subsubsection{Changes of the amount of soil DTPA-Zn after $Z n$ fertilization during the wheat life cycle.}

The DTPA extractable $\mathrm{Zn}$ can estimate the probability of whether soil can provide sufficient $\mathrm{Zn}$ to the roots to meet plant demand (Robson, 1993). The amount of soil DTPA-Zn increased on average by 2.3, 3.5, 4.7, and 5.3 fold during the life cycle of wheat in the $\mathrm{Zn}_{7.5}, \mathrm{Zn}_{15}, \mathrm{Zn}_{30}$, and $\mathrm{Zn}_{45}$ treatments, respectively, compared to the control $\left(\mathrm{Zn}_{0}\right.$ treatment)(Fig 1).

The change of soil DTPA-Zn was time- and Zn-level dependent. The amount of soil DTPA-Zn significantly increased one month after $\mathrm{Zn}_{7.5}$ and $\mathrm{Zn}_{15}$ fertilization and then declined during $30 \mathrm{~d}$ to $50 \mathrm{~d}$. The amount of soil DTPA-Zn slightly fluctuated in the $\mathrm{Zn}_{30}$ treatment during this period. From $50 \mathrm{~d}$ to $120 \mathrm{~d}$, soil DTPA- $\mathrm{Zn}$ declined in the $\mathrm{Zn}_{7.5}$ treatment and then stabilized. The trend of soil DTPA- $\mathrm{Zn}$ in the $\mathrm{Zn}_{30}$ treatment contrasted to that observed in the $\mathrm{Zn}_{7.5}$ treatment. The amount of soil DTPA-Zn was sharply reduced in the $\mathrm{Zn}_{15}$ treatment at $200 \mathrm{~d}$ and then increased. The amount of soil DTPA- $\mathrm{Zn}$ showed no significant changes in the $\mathrm{Zn}_{45}$ treatment during the wheat life cycle $(P \leq 0.05)$. 


\subsubsection{Effect of $\mathrm{Zn}$ fertilization on $\mathrm{Zn}$ concentration and accumulation in wheat tissues}

Soil $\mathrm{Zn}$ fertilization had no significant effects on $\mathrm{Zn}$ concentration and accumulation in stems, leaves, and grains. In addition, there was no significant correlation between $\mathrm{Zn}$ concentrations and $\mathrm{Zn}$ levels and between $\mathrm{Zn}$ accumulations and $\mathrm{Zn}$ levels. However, $\mathrm{Zn}$ concentration and accumulation in glumes significantly increased with increasing supply of $\mathrm{Zn}$ in soil compared to the control ( $\mathrm{Zn}_{0}$ treatment).

\subsection{Hydroponic Culture Experiment}

\subsubsection{Effects of foliar and root $\mathrm{Zn}$ supply on wheat biomass}

Zinc applied to roots or Zn foliar spray showed inhibitory effects on root biomass compared to controls. In contrast to roots, $\mathrm{Zn}$ supplementation significantly increased grain biomass compared to controls, irrespective of the supply method. Zinc foliar spray significantly increased shoot biomass on the condition that $\mathrm{Zn}$ was absent in the nutrient solution. However, a combination of $\mathrm{Zn}$ applied to root treatment with foliar $\mathrm{Zn}$ treatment significantly reduced shoot biomass compared to controls.

3.2.2 Effects of foliar $\mathrm{Zn}$ and $\mathrm{Zn}$ added to root on $\mathrm{Zn}$ concentration and distribution in wheat tissues.

Zinc supplementation to roots increased root, shoot and grain $\mathrm{Zn}$ concentration by $6.74,2.89$, and 1.84 fold, respectively compared to the control ( $\mathrm{Zn}_{0}$ treatment). Foliar $\mathrm{Zn}$ significantly increased shoot and grain $\mathrm{Zn}$ concentration compared to controls. However, with $\mathrm{Zn}$ absent in the culture solution, $\mathrm{Zn}$ foliar spray slightly increased root $\mathrm{Zn}$ concentration compared to the control $\left(\mathrm{Zn}_{0}\right.$ treatment). In contrast to this, root $\mathrm{Zn}$ concentration showed significant reduction compared to controls in the $\mathrm{Zn}$ supplied to root combined with $\mathrm{Zn}$ foliar spray treatment.

Different $\mathrm{Zn}$ supply methods showed different effects on $\mathrm{Zn}$ distribution in wheat tissues. Zinc supplementation to roots significantly reduced $\mathrm{Zn}$ distribution in shoots and grains. However, root $\mathrm{Zn}$ distribution significantly increased with increasing $\mathrm{Zn}$ concentration in the nutrient solution. This suggests that with more $\mathrm{Zn}$ in the medium, more $\mathrm{Zn}$ will be rent in roots. In contrast to $\mathrm{Zn}$ supplied to roots, $\mathrm{Zn}$ foliar spray significantly reduced root $\mathrm{Zn}$ distribution; however, $\mathrm{Zn}$ foliar spray increased shoot and grain $\mathrm{Zn}$ distribution compared to the control (spray distill water treatment), irrespectively of $\mathrm{Zn}$ levels in the nutrient solution. In this hydroponic experiment, $\mathrm{Zn}$ foliar spray or $\mathrm{Zn}$ supplied to roots increased accumulation in shoots appropriately $70 \%-90 \% \mathrm{Zn}$ compared to controls.

\section{Discussion}

\subsection{Effect of Zn fertilization methods on Zn absorption in calcareous soil}

The amount of soil DTPA-Zn is dynamic during the wheat life cycle. Fig. 1 shows that the amount of soil DTPA-Zn was reduced in wheat seedling, jointing and filling stages. This suggests that the demand of $\mathrm{Zn}$ for wheat was mainly during these stages and wheat absorbed $\mathrm{Zn}$ from soil solution primarily during these stages. This finding is consistent with Shao et al. (2005) who found that wheat absorbed Zn mainly at seedling and grain filling stages.

In this field experiment, $\mathrm{Zn}$ concentration in wheat tissues were not significantly increased with increasing $\mathrm{Zn}$ fertilizer levels in the soil with the exception of glumes. Furthermore, the utilization rate of $\mathrm{Zn}$ fertilizer was only $0.98 \%, 0.64 \%, 0.29 \%$, and $0.14 \%$ with treatments of $7.5,15,30$, and $45 \mathrm{~kg} \mathrm{Zn} \mathrm{ha}^{-1}$, respectively. A question arises as to whether there exist factors that inhibited $\mathrm{Zn}$ absorption by wheat, such as lower $\mathrm{Zn}$ bioavailability in soil. In this field experiment, the amount of DTPA-Zn was sufficient for wheat. Therefore, there must be some factors that lowered $\mathrm{Zn}$ absorption by wheat. Based on this hypothesis, a hydroponic experiment were handy to offer an explanation for the observation made. In contrast to the field experiment, in the hydroponic experiment $\mathrm{Zn}$ supplied to roots significantly increased $\mathrm{Zn}$ concentration in wheat tissues. Therefore Zhengmai 9023 showed good ability to absorb $\mathrm{Zn}$ from solution. These two experiments demonstrated that even though $\mathrm{Zn}$ levels were high in calcareous soil, wheat did not absorb additional $\mathrm{Zn}$ from the treated soil solution. A conclusion can be made that the lower absorption of Zhengmai 9023 was controlled by inhibitory factors of the soil, not the physiology of the wheat cultivar. Previous research has shown that low $\mathrm{Zn}$ concentration in wheat tissues was due to the low Zn bioavailability in soil with extreme Zn deficiency (Yilmaz et al., 1997; Cakmak, 2002). However, from our study, it seems that low $\mathrm{Zn}$ bioavailability is not the dominant inhibitory factor for low grain $\mathrm{Zn}$ concentration in calcareous soil in potentially $\mathrm{Zn}$ deficiency soils.

Zinc content of plant uptake is controlled by many factors, such as the amount of soil DTPA-Zn, transport of Zn to root surfaces and the interactions between $\mathrm{Zn}$ and other nutrients in the soil or within the plants (Robson, 1993). Zinc absorption by plants involves a number of steps (Lasat et al., 1998). First, adequate Zn 
bioavailability was necessary in the rhizoshpere. There are two pathways for $\mathrm{Zn}$ to move from the soil solution to the rhizosphere, mass flow and diffusion. In calcareous soils, diffusion is the dominant pathway for $\mathrm{Zn}$ to reach root zones. However, diffusion of $\mathrm{Zn}$ in calcareous soils is low due to low soil moisture, low organic matter and high pH (Nambiar, 1976; Holloway, 1996; Jiang et al., 2006; Alloway, 2008). Consequently, there is not sufficiently available $\mathrm{Zn}$ reaching the rhizosphere. Furthermore, some divalent ions (such as $\mathrm{Cu}^{2+}, \mathrm{Ca}^{2+}, \mathrm{Fe}^{2+}$ ) can inhibit $\mathrm{Zn}$ absorption by sharing the same carrier site in roots or by competing for transportation proteins such as zinc-regulated iron regulated protein (ZIPs) (Bowen, 1969; Nambiar, 1976; Yang et al., 2004). Therefore, in calcareous soils, it is reasonable to increase $\mathrm{Zn}$ diffusion efficiency by increasing organic matter content and irrigation management. However, additional research is needed to determine the relationships between $\mathrm{Zn}$ diffusion efficiency and $\mathrm{Zn}$ concentration in wheat grain.

\subsection{Effect of Zn fertilizer methods on Zn translocation within wheat plants}

In the hydroponic experiment, $\mathrm{Zn}$ foliar spray significantly increased $\mathrm{Zn}$ concentration in grain. However, approximately $80 \%$ of $\mathrm{Zn}$ was distributed in shoots, only $10 \%$ in grain. Zinc supplied to roots combined with $\mathrm{Zn}$ foliar spray treatments reduced root $\mathrm{Zn}$ concentrations, but increased shoot and grain $\mathrm{Zn}$ distribution compared to $\mathrm{Zn}_{3} \mathrm{~S}_{\text {water }}$ treatment. This raises the question as to whether $\mathrm{Zn}$ in grain was derived from nutrient solution or from other wheat organs such as roots and shoots. It is generally accepted that $\mathrm{Zn}$ accumulation in grain is controlled by homeostatic mechanisms in the plant that regulate $\mathrm{Zn}$ absorption, translocation, and loading and unloading rates of phloem sap (Hao et al., 2007). Palmgren et al. (2008) reported that grain Zn originates from two sources: first, directly from the soil and second, from the remobilization of stored $\mathrm{Zn}$ in leaves. In wheat, re-translocation from leaves is important for $\mathrm{Zn}$ allocation to the grain (Palmgren et al., 2008). The redistribution of $\mathrm{Zn}$ may depend on age of the plant as well as on $\mathrm{Zn}$ content of the source organs (Page and Feller, 2005). For example, senescence or limited Zn supply may limit redistribution, especially during grain filling (Erenoglu et al., 2002; Jiang et al., 2007; Palmgren et al., 2008). This was consistent with Erenoglu et al. (2002) who reported that in wheat, remobilization of $\mathrm{Zn}$ from old leaves into generative organs is much greater under low supplies than adequate supplies of $\mathrm{Zn}$. In contrast, Robson (1993) reported that remobilization of $\mathrm{Zn}$ from older into younger tissues was greater with adequate compared to deficient $\mathrm{Zn}$ supply. Although the source of grain $\mathrm{Zn}$ was uncertain in the hydroponic experiment, we determined that if wheat could absorb enough $\mathrm{Zn}$ from the solution, then $\mathrm{Zn}$ re-translocation to the grain from other organs was lower. The translocation of $\mathrm{Zn}$ in wheat plants was also low. It has been determined that over-expression of a $\mathrm{Zn}$ transporter can provide a new strategy for increasing Zn content of wheat (Ramesh et al., 2004). Palmgren et al. (2008) had determined that increased expression of genes encoding $\mathrm{Zn}$ transporters can increase $\mathrm{Zn}$ uptake in plants. Furthermore, with respect to root-to-shoot allocation of $\mathrm{Zn}$, the $\mathrm{Zn}$ pump HMA4 seems to be a major player in dicots. However, it remains to be tested whether HMA4 might be used for transgenic biofortification approaches in cereals (Pahlavan-Rad et al., 2009).

\section{Conclusion}

We can conclude that in calcareous soils, $\mathrm{Zn}$ fertilization to potentially $\mathrm{Zn}$-deficient calcareous soils was not an effective approach to increase grain $\mathrm{Zn}$ concentration by lower absorption. If wheat can absorb sufficient $\mathrm{Zn}$ from soil solution, $\mathrm{Zn}$ foliar spray will possibly have little effect on increasing $\mathrm{Zn}$ concentration in grain. This would depend on sufficient $\mathrm{Zn}$ being absorbed by roots. However, the low translocation of $\mathrm{Zn}$ in wheat plants was also an inhibitory factor to increase grain $\mathrm{Zn}$ concentration. In calcareous soils, methods in which to increase $\mathrm{Zn}$ absorption by wheat should be of high priority.

\section{References}

Alloway, B. J. (2004). Zinc in Soils and Crop Nutrition. International Zinc Association Communications. IZA Publications, Brussel.

Alloway, B. J. (2008). Zinc in Soils and Crop Nutrition. Second edition, published by IZA and IFA Brussels, Belgium and Paris, France.

Asad, A., \& Rafique, R. (2000). Effect of zinc, copper, iron, manganese and boron on the yield and yield components of wheat crop in Tehsil Peshawar. Pakistan Journal of Biological Sciences, 310, 1615-1620.

Bowen, J. E. (1969). Absorption of copper, zinc, and manganese by sugarcane leaf tissue. Plant Physiology, 44, 255-261.

Cakmak, I., Sari, N., Marschner, H., Kalayci, M., Yilmaz, A., Eker, S., \& Gülüt, K.Y. (1996). Dry matter production and distribution of zinc in bread and durum wheat genotypes differing in zinc efficiency. Plant Soil, $180,173-181$. 
Cakmak, I., Yilmaz, A., Kalayci, M., Ekiz, H., Torun, B., Erenoglu, B., \& Braun, H. J. (1996). Zinc deficiency as a critical problem in wheat production in Central Anatolia. Plant Soil, 180, 165-172.

Cakmak, I., Kalayci, M., Ekiz, H., Braun, H.J., Kilinc, Y., \& Yilmaz, A. (1999). Zinc deficiency as a practical problem in plant and human nutrition in Turkey: A NATO-science for stability project. Field Crop Research, 60, $175-188$

Cakmak, I. (2002). Plant nutrition research: Priorities to meet human needs for food in sustainable ways. Plant Soil, 247, 3-24.

Cakmak, I., Torun, A., Millet, E., Feldman, M., Fahima, T., Korol, A., Nevo, E., Braun, H. J., \& Özkan, H. (2004). Triticum dicoccoides: an important genetic resource for increasing zinc and iron concentration in modern cultivated wheat. Soil Science \& Plant Nutrition, 50, 1047-1054.

Erenoglu, B., Nikolic, M., Römheld, V., \& Cakmak, I. (2002). Uptake and transport of foliar applied zinc $\left({ }^{65} \mathrm{Zn}\right)$ in bread and durum wheat cultivar differing in zinc efficiency. Plant Soil, 241, 251-257.

Garnett, T. P., \& Graham R. D. (2005). Distribution and remobilization of iron and copper in wheat. Annals of Botany, 95, 817-826.

Graham, R. D., \& Rengel, Z. (1993). Genotypic variation in zinc uptake and utilization by plants. Zinc in Soils and Plants. Kluwer Academic Publishers, Dordrecht, pp107-114.

Gunes, A., Inal, A., Adak, M. S., Alpaslan, M., Bagci, E. G., Erol, T., \& Pilbeam, D. J. (2007). Mineral nutrition of wheat, chickpea and lentil as affected by mixed cropping and soil moisture. Nutrient Cycling in Agroecosystems, 78, 83-96.

Hao, H. L., Wei, Y. Z., Yang, X. E., Feng, Y., \& Wu, C. Y. (2007). Effects of different nitrogen fertilizer levels on $\mathrm{Fe}, \mathrm{Mn}, \mathrm{Cu}$ and $\mathrm{Zn}$ concentrations in shoot and grain quality in rice (Oryza sativa). Rice Science, 14 (4), 289-294.

Hao, M. D., Wei, X. R., \& Dang, T. H. (2003). Effect of long-term applying zinc fertilizer on wheat yield and content of zinc in dryland. Plant Nutrition and Fertilizer Science, 9(3), 377-380 (In Chinese).

Hotz, C., \& Brown, K. H. (2004). Assessment of the risk of zinc deficiency in populations and options for its control. Food and Nutrition Bulletin, 25, 94-203.

Holloway, R. E. (1996). Zinc as a subsoil nutrient for cereals. Roseworthy, South Australia (a thesis).

Jiang. W., Struik, P. C., Lingna, J., Keulen, H. V., Ming, Z., \& Stomph, T. J. (2007). Uptake and distribution of root-applied or foliar-applied ${ }^{65} \mathrm{Zn}$ after flowering in aerobic rice. Annals Applied Biology, 150, 383-391.

Jiang, W., Zhao, M., Fan, T. Q., \& Jin, L. N. (2006). Physiology of zinc uptake partitioning and approaches to increasing zinc density in grains of food crops. China Soils and Fertilizer, 4, 10-15.

Kaya, C., Higgs, D., \& Burton, A. (1999). Foliar application of iron as a remedy for zinc toxic tomato plants. Journal of Plant Nutrition, 22, 1829-1837.

Lasat, M. M., Baker, A. J. M., \& Kochian, L.V. (1998). Altered Zn compartmentation in the root symplasm and stimulated $\mathrm{Zn}$ absorption into the leaf as mechanisms involved in $\mathrm{Zn}$ hyperaccumulation in Thlaspi caerulescens. Plant Physiology, 118, 875-883.

Muminjanov, H., Morgounov, A., \& Cakmak, I. (2007). Variation of zinc and iron content in wheat grain in Tajikistan. [Online] Available: http://www.zinc-crops.Org/ZnCrops2007/PDF/2007_zinccrops 2007-muminjanov_abstract.pdf) (2007).

Nambiar, E. K. S. (1976). The uptake of zinc-65 by oats in relation to soil water content and root growth. Australian salinity in lowland rice systems. Field Crop Research, 56, 139-155.

Page, V., \& Feller, U. (2005). Selective transport of zinc, managenes, nickel, cobalt and cadmium in the root system and transfer to the leaves in young wheat plants. Annals of Botany, 96, 425-434.

Palmgren, M. G., Clemens, S., Williams, L. E., Kramer, U., Borg, S., Schjørring, J. K., \& Sanders, D. (2008). Zinc biofortification of cereals: problems and solutions. Trends in Plant Science, 13, 464-473.

Pahlavan-Rad, M. R., \& Pessarakli, M. (2009). Response of wheat plants to zinc, iron, and manganese applications and uptake and concentration of zinc, iron, and manganese in wheat grains. Communications in Soil Science and Plant Analysis, 40, 1322-1332.

Ramesh, S. A., Choimes, S., \& Schachtman, D. P. (2004). Over-expression of an Arabidopsis zinc transporter in 
Hordeum vulgare increase short-term zinc uptake after zinc deprivation and seed zinc content. Plant Molecular Biology, 54, 373-385.

Robson, A. D. (1993). Zinc uptake from soils in Zinc in soils and plants, Kluwer Academic Publishers, The Netherlands.

Shao, Y., Jiang, L. N., Li, C. X., Li, X. L., \& Lu, X. Y. (2005). Study on uptake, distribution and accumulation of $\mathrm{Zn}$ in wheat. Journal of Triticeae Crops, 5(1), 82-85 (In Chinese).

WHO. (2002). The World Health Report: Reducing Risks, Promoting Healthy Life. World Health Organization.

Yang, X. E., Long, X. X., Ye, H. B., He, Z. L., Calvert, D. V., \& Stoffella, P. J. (2004). Cadmium tolerance and hyperaccumulation in a new Zn-hyperaccumulating plant species (Sedum alfredii Hance). Plant Soil, 259, 181-189.

Yang, X. E., Chen, W. R., \& Feng, Y. (2007). Improving human micronutrient nutrition through biofortification in the soil-plant system: China as a case study. Environmental Geochemistry and Health, 29, 413-428.

Yilmaz, A., Ekiz, H., Torun, B., Gultekin, I., Karanlik, S., \& Bagci, S. A. (1997). Effect of different zinc application methods on grain yield and zinc concentrations in wheat cultivars grown on zinc-deficiency calcareous soils. Journal of Plant Nutrition, 20, 461-471.

Table 1. Characteristics of tested soil

\begin{tabular}{|c|c|c|c|c|c|c|c|}
\hline Taxonomic classification & $\mathrm{pH}$ & $\begin{array}{c}\text { Organic matter } \\
(\mathrm{g} / \mathrm{kg})\end{array}$ & $\begin{array}{c}\text { Olsen-P } \\
(\mathrm{mg} / \mathrm{kg})\end{array}$ & $\begin{array}{c}\text { Available-K } \\
(\mathrm{mg} / \mathrm{kg})\end{array}$ & $\begin{array}{c}\mathrm{CaCO}_{3} \\
(\mathrm{~g} / \mathrm{kg})\end{array}$ & $\begin{array}{c}\text { DTPA-Zn } \\
(\mathrm{mg} / \mathrm{kg})\end{array}$ & $\begin{array}{c}\text { Total-Zn } \\
(\mathrm{mg} / \mathrm{kg})\end{array}$ \\
\hline Eum-Otrthic Anthrosols & 7.98 & 13.79 & 17.2 & 166.2 & 65.1 & 0.67 & 69.78 \\
\hline
\end{tabular}

Table 2. Effect of $\mathrm{Zn}$ fertilization on $\mathrm{Zn}$ concentration and accumulation in wheat tissues. ${ }^{\mathrm{a}, \mathrm{b}, \mathrm{c}}$ Values in the same column followed by the same letter are not significantly different at the $\mathrm{P}=0.05$ level

\begin{tabular}{|c|c|c|c|c|c|c|c|c|}
\hline \multirow{2}{*}{ Treatment } & \multicolumn{3}{|c|}{ Zn concentration $(\mathrm{mg} / \mathrm{kg})$} & \multicolumn{3}{c|}{ Zn accumulation (g/ha) } \\
\cline { 2 - 9 } & Stem & Leaf & Grain & Glume & Stem & Leaf & Grain & Glume \\
\hline $\mathrm{Zn}_{0}$ & $22.50 \mathrm{a}$ & $18.12 \mathrm{a}$ & $31.32 \mathrm{a}$ & $16.18 \mathrm{~b}$ & $69.37 \mathrm{a}$ & $17.12 \mathrm{a}$ & $164.38 \mathrm{a}$ & $32.95 \mathrm{~b}$ \\
\hline $\mathrm{Zn}_{7.5}$ & $17.68 \mathrm{a}$ & $17.76 \mathrm{a}$ & $33.14 \mathrm{a}$ & $21.22 \mathrm{ab}$ & $64.61 \mathrm{a}$ & $20.15 \mathrm{a}$ & $168.56 \mathrm{a}$ & $41.20 \mathrm{ab}$ \\
\hline $\mathrm{Zn}_{15}$ & $15.82 \mathrm{a}$ & $22.89 \mathrm{a}$ & $37.10 \mathrm{a}$ & $22.12 \mathrm{ab}$ & $66.18 \mathrm{a}$ & $28.29 \mathrm{a}$ & $183.73 \mathrm{a}$ & $56.33 \mathrm{a}$ \\
\hline $\mathrm{Zn}_{30}$ & $15.93 \mathrm{a}$ & $22.78 \mathrm{a}$ & $41.42 \mathrm{a}$ & $21.22 \mathrm{ab}$ & $59.16 \mathrm{a}$ & $33.31 \mathrm{a}$ & $214.21 \mathrm{a}$ & $55.15 \mathrm{a}$ \\
\hline $\mathrm{Zn}_{45}$ & $26.50 \mathrm{a}$ & $20.45 \mathrm{a}$ & $34.77 \mathrm{a}$ & $25.67 \mathrm{a}$ & $102.49 \mathrm{a}$ & $29.00 \mathrm{a}$ & $169.85 \mathrm{a}$ & $61.26 \mathrm{a}$ \\
\hline
\end{tabular}


Table 3. Effects of Zn supplied to roots and Zn foliar spray on wheat biomass (g). ${ }^{\mathrm{a}, \mathrm{b}, \mathrm{c}} \mathrm{Values}$ in the same column followed by the same letter are not significantly different at the $\mathrm{P}=0.05$ level

\begin{tabular}{|c|c|c|c|c|}
\hline \multicolumn{2}{|c|}{ Treatment } & Root (g) & Shoot $(\mathrm{g})$ & Grain (g) \\
\hline $\mathrm{Zn}$ added to roots & Spraying time & & & \\
\hline \multirow{4}{*}{$\mathrm{Zn}_{0}$} & Control & $0.34 \pm 0.01 \mathrm{a}^{(\text {note } 1)}$ & $2.25 \pm 0.07 \mathrm{e}$ & $0.30 \pm 0.02 \mathrm{~d}$ \\
\hline & Jointing & $0.24 \pm 0.03 \mathrm{e}$ & $2.30 \pm 0.09 \mathrm{e}$ & $0.72 \pm 0.05 b$ \\
\hline & Heading & $0.35 \pm 0.05 a$ & $2.83 \pm 0.11 \mathrm{a}$ & $0.88 \pm 0.04 a$ \\
\hline & Flowering & $0.31 \pm 0.04 \mathrm{~b}$ & $2.57 \pm 0.08 \mathrm{~b}$ & $0.84 \pm 0.03 \mathrm{a}$ \\
\hline \multirow{4}{*}{$\mathrm{Zn}_{3}$} & Control & $0.28 \pm 0.05 \mathrm{c}$ & $2.44 \pm 0.07 \mathrm{c}$ & $0.66 \pm 0.02 \mathrm{c}$ \\
\hline & Jointing & $0.26 \pm 0.03 \mathrm{de}$ & $2.30 \pm 0.06 \mathrm{de}$ & $0.76 \pm 0.03 b$ \\
\hline & Heading & $0.27 \pm 0.03 \mathrm{~cd}$ & $2.42 \pm 0.05 \mathrm{~cd}$ & $0.89 \pm 0.07 \mathrm{a}$ \\
\hline & Flowering & $0.25 \pm 0.06 \mathrm{de}$ & $2.29 \pm 0.08 \mathrm{e}$ & $0.87 \pm 0.06 \mathrm{a}$ \\
\hline \multicolumn{5}{|c|}{$p$ values of the significance of the LSD } \\
\hline \multicolumn{2}{|c|}{$\mathrm{Zn}$} & $\mathrm{P}<0.001$ & $\mathrm{P}<0.001$ & $\mathrm{P}<0.001$ \\
\hline \multicolumn{2}{|c|}{$\mathrm{S}$} & $\mathrm{P}<0.001$ & $\mathrm{P}<0.001$ & $\mathrm{P}<0.001$ \\
\hline \multicolumn{2}{|c|}{$\mathrm{Zn} \times \mathrm{S}$} & $\mathrm{P}<0.001$ & $\mathrm{P}<0.001$ & $\mathrm{P}<0.001$ \\
\hline
\end{tabular}

Table 4. Effects of $\mathrm{Zn}$ supplied to root and $\mathrm{Zn}$ foliar spray on $\mathrm{Zn}$ concentration and distribution. ${ }^{\text {a,b,c }} \mathrm{Values}$ in the same column followed by the same letter are not significantly different at the $\mathrm{P}=0.05$ level.

\begin{tabular}{|c|c|c|c|c|c|c|c|}
\hline \multicolumn{2}{|c|}{ Treatment } & $\begin{array}{c}\text { Root } \\
(\mathrm{mg} / \mathrm{kg})\end{array}$ & $\begin{array}{c}\text { Shoot } \\
(\mathrm{mg} / \mathrm{kg})\end{array}$ & $\begin{array}{c}\text { Grain } \\
(\mathrm{mg} / \mathrm{kg})\end{array}$ & $\begin{array}{c}\text { Root } \\
\%\end{array}$ & $\begin{array}{c}\text { Shoot } \\
\%\end{array}$ & $\begin{array}{c}\text { Grain } \\
\%\end{array}$ \\
\hline $\mathrm{Zn}$ to root & Foliar Zn & & & & & & \\
\hline \multirow{4}{*}{$\mathrm{Zn}_{0}$} & Control & $49.98 \mathrm{~d}$ & $25.38 \mathrm{f}$ & $18.68 d$ & $22.81 b$ & $77.19 \mathrm{c}$ & $7.15 \mathrm{~d}$ \\
\hline & Jointing & $57.58 \mathrm{~d}$ & $38.84 \mathrm{e}$ & $19.95 \mathrm{~cd}$ & $13.58 \mathrm{c}$ & $86.42 b$ & $12.20 \mathrm{a}$ \\
\hline & Heading & $58.94 d$ & $47.65 d$ & $20.76 \mathrm{c}$ & $13.41 \mathrm{c}$ & $86.59 \mathrm{~b}$ & $10.53 b$ \\
\hline & Flowering & $54.72 \mathrm{~d}$ & $56.42 \mathrm{c}$ & $19.32 d$ & $10.37 \mathrm{~d}$ & $89.63 a$ & $9.11 \mathrm{c}$ \\
\hline \multirow{4}{*}{$\mathrm{Zn}_{3}$} & Control & $404.71 \mathrm{a}$ & $106.49 \mathrm{~b}$ & $33.74 b$ & $30.28 \mathrm{a}$ & $69.72 \mathrm{e}$ & $5.61 \mathrm{e}$ \\
\hline & Jointing & $340.89 \mathrm{c}$ & $125.94 \mathrm{a}$ & $36.88 \mathrm{a}$ & $23.28 \mathrm{~b}$ & $76.72 \mathrm{~cd}$ & $6.93 \mathrm{~d}$ \\
\hline & Heading & $368.18 b$ & $126.37 \mathrm{a}$ & $37.77 \mathrm{a}$ & $24.49 \mathrm{~b}$ & $75.51 \mathrm{~d}$ & $7.72 d$ \\
\hline & Flowering & $376.63 b$ & $126.98 \mathrm{a}$ & $36.59 \mathrm{a}$ & $24.36 \mathrm{~b}$ & $75.64 \mathrm{~cd}$ & $7.62 d$ \\
\hline \multicolumn{8}{|c|}{$p$ values of the significance of the LSD } \\
\hline \multicolumn{2}{|c|}{$\mathrm{Zn}$} & $\mathrm{P}<0.001$ & $\mathrm{P}<0.001$ & $\mathrm{P}<0.001$ & $\mathrm{P}<0.001$ & $\mathrm{P}<0.001$ & $\mathrm{P}<0.001$ \\
\hline \multicolumn{2}{|c|}{$\mathrm{S}$} & $\mathrm{P}<0.001$ & $\mathrm{P}<0.001$ & $\mathrm{P}<0.001$ & $\mathrm{P}<0.001$ & $\mathrm{P}<0.001$ & $\mathrm{P}<0.001$ \\
\hline \multicolumn{2}{|c|}{$\mathrm{Zn} \times \mathrm{S}$} & $\mathrm{P}<0.001$ & $\mathrm{P}<0.001$ & $\mathrm{P}=0.068$ & $\mathrm{P}<0.001$ & $\mathrm{P}<0.001$ & $\mathrm{P}<0.001$ \\
\hline
\end{tabular}

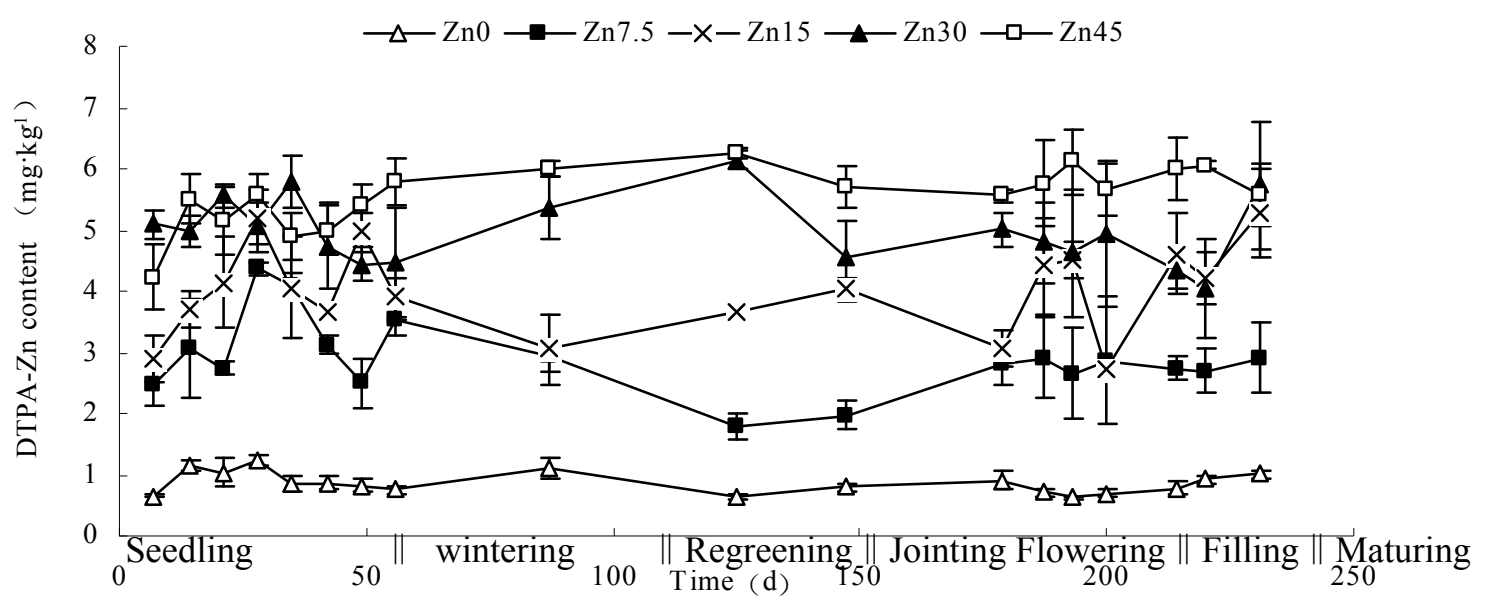

Figure 1. Changes in the amount of soil DTPA-Zn after $\mathrm{Zn}$ fertilization during the wheat life cycle 